\title{
Kompetensi Guru dan Kaitannya dengan Pengembangan
}

\author{
Materi Ajar Bahasa Indonesia
}

\section{Pendahuluan}

Tuntutan guru profesional merupakan salah satu kompetensi yang harus dimiliki guru . Kompetensi profesional seorang guru dengan memiliki kompetensi antara lain dapat mengembangkan profesionalisme secara berkelanjutan dengan melakukan tindakan reflektif, dan menggunakan TIK untuk berkomunikasi dan mengembangkan diri (Syahrul Ramadhan, Sukma, Indriyani, Bahasa, \& Padang, 2019). Artinya, pelatihan publikasi ilmiah bagi guru merupakan pengembangan profesional dalam bentuk karya sebagai tindakan reflektif bagi guru profesional. Guru profesional harus mampu beradaptasi dengan perkembangan teknologi yang semakin canggih (Novauli, 2015). Ini akan menguji keberadaan guru profesional dengan kemampuannya menggunakan media dan sumber belajar berbasis digital (S. Ramadhan, Atmazaki, Sukma, \& Indriyani, 2021).

Menurut (Syahrul Ramadhan, Sukma, \& Indriyani, 2019), Pendidikan adalah kunci untuk membangun sebuah bangsa. Pendidikan menciptakan insan-insan berbakat yang mampu bersaing dalam perkembangan ilmu pengetahuan dan teknologi. Perkembangan ilmu pengetahuan dan teknologi adalah untuk menciptakan kondisi di mana semua negara dapat meningkatkan kualitas pendidikan. Guru merupakan faktor penting dalam menentukan kemajuan pendidikan. Oleh karena itu, kualifikasi guru perlu terus dipertahankan dan ditingkatkan. Kegiatan belajar menentukan kualitas seorang guru. Pemerintah menetapkan standar kebijakan kurikulum dengan tujuan meningkatkan kualitas pendidikan, tetapi guru 
biasanya melakukannya dan menentukan apakah kualitas pembelajaran mempengaruhi kualitas pendidikan. Selanjutnya menurut (Domalewska, 2014), penggunaan multimedia TIK seperti suara, animasi, dan gambar dapat melibatkan siswa dalam belajar dan meningkatkan pengetahuan mereka dan memotivasi mereka untuk belajar yang lebih baik. Penggunaan multimedia bertujuan untuk memudahkan siswa dalam menentukan apa dan bagaimana mereka dapat menyerap informasi secara cepat dan efisien (Mulyadi, Syahrul, Atmazaki, \& Agustina, 2020). Kemampuan teknologi multimedia yang semakin baik dan berkembang akan menambah kemudahan dalam memperoleh pengetahuan siswa. (Hamzah \& Muhlisrarini, 2014) mengatakan bahwa penggunaan multimedia dalam pembelajaran memegang peranan penting dalam nilai akademik belajar siswa. Dengan multimedia diharapkan siswa akan lebih mudah untuk menentukan apa dan bagaimana siswa dapat menyerap informasi dengan cepat dan efisien karena sumber belajar tidak lagi terfokus pada buku pelajaran.

Bahasa memegang peranan penting dalam kehidupan manusia (Atmazaki, Ramadhan, Indriyani, \& Nabila, 2021). Bahasa dapat mengembangkan kecerdasan intelektual, emosional, dan kecerdasan spiritual (Tampubolon, 2018). Pengembangan modul belajar mandiri untuk pelajaran bahasa Indonesia diharapkan orientasi pembelajaran tidak lagi berpusat pada guru melainkan mengarah pada sebuah sistem pembelajaran yang berpusat pada siswa (Syahrul Ramadhan, Indriyani, Asri, \& Sukma, 2020). Kompetensi lulusan yang mampu mengembangkan konsep visual komunikasi di media digital (Mursal, Ramadhan, Ermanto, \& Atmazaki, 2019). Fokus pengembangan dalam penelitian ini terletak pada penyajian materi pembelajaran mandiri yang didalamnya terdapat pengelolaan materi, display, dan kendali peserta didik. Lantas apakah kompetensi guru ada kaitannya dengan pengembangan materi ajar bahasa indonesia? 


\section{Pembahasan}

Guru dalam proses pembelajaran di kelas dipandang dapat memainkan peran penting terutama dalam membantu peserta didik untuk membangun sikap positif dalam belajar, membangkitkan rasa ingin tahu, mendorong kemandirian dan ketepatan logika intelektual, serta menciptakan kondisi-kondisi untuk sukses dalam belajar. Kinerja dan kompetensi guru memikul tanggung jawab utama dalam transformasi orientasi peserta didik dari ketidaktahuan menjadi tahu, dari ketergantungan menjadi mandiri, dari tidak terampil manjadi terampil, dengan metode-metode pembelajaran bukan lagi mempersiapkan peserta didik yang pasif, melainkan peserta didik berpengetahuan yang senantiasa mampu menyerap dan menyesuaikan diri dengan informasi baru dengan berpikir, bertanya, menggali, mencipta dan mengembangkan cara-cara tertentu dalam memecahkan masalah yang berkaitan dengan kehidupannya (S. Ramadhan, Sukma, \& Indriyani, 2019).

Kompetensi guru adalah sebuah kapasitas dan kewenangan pendidik dalam menyelesaikan panggilan pertunjukan Muhibbin dalam (Werdayanti, 2008). Kemampuan instruktur sangat signifikan dibandingkan dengan latihan siswa dan hasil belajar. Interaksi belajar dan hasil belajar siswa tidak hanya ditentukan oleh sekolah, contoh, desain, dan isi program pendidikan, tetapi sebagian besar dikendalikan oleh kemampuan instruktur yang mendidik dan membimbing mereka. Menurut (Suryosubroto, 2002) ukuran pengajaran dan pembelajaran mencakup latihan-latihan yang dilakukan oleh instruktur mulai dari menyusun, melaksanakan latihan hingga penilaian dan program tindak lanjut yang terjadi dalam keadaan instruktif untuk mencapai tujuan tertentu, khususnya mendidik (S. Ramadhan et al., 2019).

Sesuatu yang dapat dimasukkan ke dalam pengajaran yang dapat diterima adalah dengan bantuan inovasi dalam pembelajaran adalah pemanfaatan materi peragaan yang terkomputerisasi, khususnya dalam pembelajaran bahasa Indonesia yang dapat memanfaatkan 
perangkat keras, baik berupa buku, modul, lembar kerja siswa, dll.(Yasuda, Zhang, Yamamoto, \& Sumita, 2008). Menampilkan materi adalah salah satu segmen penting dalam pembelajaran bahasa (Meli, 2015). Menyelesaikan materi yang ditampilkan akan membantu memperkuat substansi dan minat siswa dengan memberikan penjelasan dan praktik yang berbeda dan memperluas materi dengan menambahkan berbagai komponen yang berharga bagi siswa (Islam dan Mares, 2003) dalam (Tabari, 2013). Menampilkan materi secara signifikan akan mempengaruhi sifat pembelajaran di kelas karena menunjukkan materi adalah metode yang ampuh untuk mencerminkan pembelajaran (Richards \& Renandya, 2002). Menampilkan materi direncanakan tergantung pada pengamanan dan kemajuan pengajaran, sehingga materi menunjukkan dapat menjadi hotspot untuk campur tangan dan bekerja dengan mendidik dan belajar (Tomlinson, 2007).

\section{Penutupan}

Pengajar memegang peranan penting dalam mencapai tujuan pembelajaran, karena pendidik dapat menentukan jumlah dan sifat pertunjukan yang mereka lakukan. Untuk memperoleh pembelajaran yang berkualitas, diperlukan kemampuan seseorang. Pengajar sebagai pendidik sumber informasi yang dibutuhkan oleh siswa, instruktur harus memiliki informasi ini, dengan memiliki informasi dan kemampuan yang besar, jelas instruktur akan benar-benar ingin mengatasi masalah yang ada di kelas.

Guru berkonotasi pada sejauhmana seseorang melakukan aktivitas baik yang berkenaan dengan tugas dan kewajiban yang sesuai dengan tingkat kompetensi yang dikuasainya atau dengan kata lain kinerja sebagai perilaku lebih banyak dimotori dan dikoordinasikan oleh sejumlah pengetahuan maupun informasi yang dikuasai seseorang dalam melak-sanakan kegiatan sesuai dengan tuntutan tugasnya. Kinerja guru dapat dinyatakan sebagai tingkat keberhasilan seorang guru secara keseluruhan dalam periode waktu tertentu 
yang dapat diukur berdasarkan tiga indikator yaitu: penguasaan bahan ajar, kemampuan mengelola pembelajaran, dan komitmen menjalankan tugas.

\section{DAFTAR PUSTAKA}

Atmazaki, Ramadhan, S., Indriyani, V., \& Nabila, J. (2021). Dialogic-Interactive Media Design for Language Learning to Improve Speaking Activities and Skills. Journal of Physics: Conference Series, 1779.

Domalewska, D. (2014). Technology-supported classroom for collaborative learning: Blogging in the foreign language classroom. International Journal of Education and Development Using Information and Communication Technology (IJEDICT), 10(4).

Hamzah, A., \& Muhlisrarini. (2014). Perencanaan dan Strategi Pembelajaran Matematika. Jakarta: Rajagrafindo Persada.

Meli. (2015). Evaluasi Penyusunan Materi Pengajaran Fonetik Pada Bahan Ajar Bahasa Mandarin. Jurnal Bahasa \& Sastra, 15(2).

Mulyadi, Syahrul, R., Atmazaki, \& Agustina. (2020). The Development of E-Modules Based on Adobe Flash for Indonesian Subjects at IAIN Bukittinggi. Journal of Physics: Conference Series, 1471.

Mursal, Ramadhan, S., Ermanto, \& Atmazaki. (2019). The Development of A Fairy Tale Text Learning Model Using Problem Based Learning Approach in Class IV Elementary School. Proceedings of the Eighth International Conference on Languages and Arts, 463.

Novauli, M. F. (2015). Kompetensi Guru Dalam Peningkatan Prestasi Belajar Pada Smp Negeri 
Dalam Kota Banda Aceh. Jurnal Administrasi Pendidikan: Program Pascasarjana Unsyiah, 3(1).

Ramadhan, S., Atmazaki, Sukma, E., \& Indriyani, V. (2021). Design of task-based digital language teaching materials with environmental education contents for middle school students. Journal of Physics: Conference Series PAPER, 1811.

Ramadhan, S., Sukma, E., \& Indriyani, V. (2019). Teacher competence in utilizing digital media literacy in education. Journal of Physics: Conference Series, 1339.

Ramadhan, Syahrul, Indriyani, V., Asri, Y., \& Sukma, E. (2020). Design of Learning Modules Writing Narrative Text Based on Project Based Learning (PjBL) by Using Mobile Devices. Journal of Physics: Conference Series, 1471(1).

Ramadhan, Syahrul, Sukma, E., \& Indriyani, V. (2019). Environmental education and disaster mitigation through language learning. Earth and Environmental Science.

Ramadhan, Syahrul, Sukma, E., Indriyani, V., Bahasa, F., \& Padang, U. N. (2019). Bahasa Indonesia Dengan Perangkat Seluler. Seminar Internasional Riksa Bahasa XIII.

Richards, J. C., \& Renandya, W. A. (2002). Methodoly in Language Teaching: An Anthology of Current Practice. Cambridge: Cambridge University.

Suryosubroto. (2002). Proses Belajar Mengajar Di Sekolah. Jakarta: PT Rineka Cipta.

Tabari, A. G. (2013). Challenges of Language Syllabus Design in EFL/ESL Contexts. Journal of Language Teaching and Research, 4(4).

Tampubolon, D. P. (2018). Bahasa dan kecerdasan dalam berkomunikasi. Jurnal Ilmiah Ilmu Komunikasi, 1(1).

Tomlinson, M. (2007). Graduate employability and student attitudes and orientations to the labour market. Journal of Education and Work, 20(4). 
Werdayanti, A. (2008). aPengaruh Kompetensi Guru Dalam Proses Belajar Mengajar Di Kelas Dan Fasilitas Guru Terhadap Motivasi Belajar Siswa. Dinamika Pendidikan, 3(1).

Yasuda, K., Zhang, R., Yamamoto, H., \& Sumita, E. (2008). Method of Selecting Training Data to Build a Compact dan Efficient Translation Model. Proceedings of the International Joint Conference on Natural Language Processing (IJCNLP). Hyderabad. 